\title{
Effect of riverbed morphology, stream order and season on the structural and functional attributes of caddisfly assemblages (Insecta: Trichoptera)
}

\author{
D. Schmera ${ }^{1 *}$, T. Erôs ${ }^{2}$
}

${ }^{1}$ Plant Protection Institute, Hungarian Academy of Sciences, POB 102, H-1525 Budapest, Hungary.

${ }^{2}$ Hungarian Danube Research Station, Hungarian Academy of Sciences, Jávorka u. 14, H-2131 Göd, Hungary.

\begin{abstract}
We tested the individual and joint effects of stream order, riverbed morphology (i.e. pool-riffle sequence), and season on the structural (i.e. species composition, density and richness) and functional (i.e. percent ratio of shredders, collectors, scrapers, and predators) properties of caddisfly assemblages in a closely natural headwater system (Börzsöny Mts., North Hungary). Each factor, both individually and in interaction had a significant effect on caddisfly assemblages as shown by MANOVA analyses. To clarify the effects of stream order, riverbed morphology and season on caddisflies, assemblage properties were also separately studied by ANOVAs. Percent ratio of shredders and collectors were strongly affected by all factors, whereas other attributes were not always sensitive to stream order, season and riverbed morphology. In contrast, species compositions of the reaches differing in stream order and riverbed morphology were significantly different. Our findings on the contrasting differences in shredder composition between riffles and pools may suggest that not only riparian vegetation, but also instream habitat features could shape the accumulation and retention of particulate organic matter (in streams with pool-riffle heterogeneity).
\end{abstract}

Keywords : Trichoptera, assemblage structure and function, channel unit, riffle, pool, stream.

\section{Introduction}

The abiotic habitat template is generally considered as the major determinant of community organisation in running waters, at many spatial and temporal scales (Hynes 1970, Townsend 1989, Ward 1989, Allan 1995, Townsend et al. 1997, Boyero 2003a, Parson et al. 2003). In headwater streams particularly, the physical habitat of benthic animals show contrasting changes at relatively small scales, thus generating considerable spatial heterogeneity (Boyero 2003b, 2003c). This spatial heterogeneity strongly influences the distribution of stream-dwelling organisms (Allan 1995). Studies conducted at the reach scale (linear spatial scale: several tens of metres, Giller \& Malmqvist 1998) showed that stream order (Strahler 1952) had a broad capability of predicting the structural and/or functional properties of macroinvertebrate communi-

* Corresponding author : E-mail: schmera@julia-nki.hu ties (Vinson \& Hawkins 1998), including caddisflies (Wiberg-Larsen et al. 2000, Park et al. 2003, Céréghino et al. 2003). Beside stream order, environmental heterogeneity may strongly influence the assemblage characteristics of macroinvertebrate communities at the mesohabitat scale (i.e., a few metres, Vinson \& Hawkins 1998, Bournaund et al. 1998, Beisel et al. 1998, 2000; Usseglio-Polatera et al. 1999).

While many studies focused on the structure of stream macroinvertebrate communities at the mesohabitat (Beisel et al. 1998) and the reach (e.g. González et al. 2003) scales, the number of investigations at the subreach (channel unit, or pool-riffle) spatial scale (i.e. between the mesohabitat and the reach, Giller \& Malmqvist 1998) remain somehow limited (but see Brown \& Brussock 1991, Brussock \& Brown 1991, Carter \& Fend 2001, Rabeni et al. 2002). At the subreach spatial scale, riverbed morphology shows an alternating sequence of pool and riffle habitats. By definition pools are slowly flowing depositional zones dominated by fine particles of mineral substrates; while 
riffles are turbulent, shallower, fast flowing and erosional zones dominated by large particles of mineral substrates (Brussock \& Brown 1991, Gordon et al. 1992, Giller \& Malmqvist 1998). The contrasting differences in abiotic (e.g. current velocity, substrate composition, water depth) as well as biotic (e.g. food sources, predation) factors between riffles and pools may exert a strong effect on the organisation of macroinvertebrate assemblages (Allan 1995, Rabeni 2002). In fact, riffles are generally considered to support higher densities of benthic macroinvertebrates contrast to pools (Hynes 1970, Kerans et al. 1992, Allan 1995, Weigel et al. 2003, Townsend et al. 2004). However, information on the similarities and differences in assemblage diversity of certain taxonomical groups remains too sporadic to allow general conclusions (Vinson \& Hawkins 1998).

In this paper, we examined the individual and joint effects of (1) season, (2) stream order and (3) riverbed morphology (i.e. pools vs. riffles) on the structural and functional properties of caddisfly assemblages in a closely natural, headwater stream system receiving deciduous litter input in the Börzsöny Mts, Hungary. Caddisflies (Insecta: Trichoptera) were selected as study organisms because they inhabit different kinds of substrates (Higler 1975, Habdija et al. 2002) within various flow regime (Bacher \& Waringer 1996), and represent a variety of functional feeding groups (Cummins 1973, Giller \& Malmqvist 1998).

\section{Material and methods}

\section{Study area and field sampling}

The study was carried out in the northern part of the Börzsöny Mountains, Hungary $\left(47^{\circ} 50^{\prime}-48^{\circ} 05^{\prime} \mathrm{N}\right.$, $\left.18^{\circ} 45^{\prime}-19^{\circ} 05^{\prime} \mathrm{E}\right)$ : The Kemence stream system belongs to the Danube drainage basin. It meanders through an oak-hornbeam woodland (Querco-Carpinetum) with riparian vegetation dominated by alder (Alnus glutinosa). The canopy provides extensive shading and leaves little light for instream primary production. Hence, the primary production of the Kemence stream system is mostly based on allochthonous leaf litter from the surrounding riparian vegetation. Two study sites were chosen: one site was in the tributary of the Kemence stream (i.e. the second order Bernecei stream), and the other site was in the third order section of the Kemence mainstream. These sites were randomly taken from the pool of possible candidate sites that represented the diversity of habitats in the stream system (see Erős et al. 2003 for a detailed methodology). The Bernecei and the Kemence have a well developed riffle-pool morphology with gravel as the dominant substratum (Erôs et al. 2003), and basically the same physical and chemical characteristics (Table 1). Riffle-pool riverbed morphology however, is more contrasting in the third order (i.e. Kemence) than in the second order (i.e. Bernecei) section. The Kemence stream system is among the reasonable representative of the closely natural submontane streams of the Carpathian region in Central Europe.

Table 1.Chemical and physical characteristics of the Bernecei and Kemence streams. Note that habitat data describe the average characteristics of the studied sites.

\begin{tabular}{lcc}
\hline & Bernecei stream & Kemence stream \\
\hline $\mathrm{pH}$ & $7.8-8.6$ & $7.7-8.5$ \\
Conductivity $\mu \mathrm{S} / \mathrm{cm})$ & $450-580$ & $310-550$ \\
Dissolved Oxygen $(\mathrm{mg} / \mathrm{l})$ & $7.3-11.1$ & $8.5-11.8$ \\
Salinity $(\%)$ & 0.02 & $0.01-0.02$ \\
Stream order & $2^{\text {nd }}$ & $3^{\text {rd }}$ \\
Width $(\mathrm{m})$ & $1.4-4.1$ & $3.5-7.0$ \\
Average current velocity $(\mathrm{m} / \mathrm{s})$ & $0-30$ & $1.5-50$ \\
$\%$ Silt $(<0.005 \mathrm{~cm})$ & 10 & 15 \\
$\%$ Sand $(0.005-0.2 \mathrm{~cm})$ & 20 & 15 \\
$\%$ Gravel $(0.2-6 \mathrm{~cm})$ & 50 & 45 \\
$\%$ Stone $(6-30 \mathrm{~cm})$ & 13 & 20 \\
$\%$ Rock $(>30 \mathrm{~cm})$ & 5 & 2 \\
Claystone $(\%)$ & 2 & 3 \\
\hline
\end{tabular}


Caddisfly larvae were collected on three sampling dates (April, August and October) in 2001. At every sampling occasion, three replicates of Surber samples (area: $0.0625 \mathrm{~m}^{2}$, mesh size $500 \mu \mathrm{m}$ ) were randomly taken from the mid-channel of riffle and pool habitats at each site. Hence, altogether 36 samples were taken over the whole year [3 (replicates) x 2 (pool and riffle) $\mathrm{x} 2$ (stream order : $2^{\text {nd }}$ order Bernecei stream, $3^{\text {rd }}$ order Kemence stream) x 3 (season: April, August and October). We acknowledge that the number of replicate samples per date per channel unit was rather limited. However, other studies successfully demonstrated the patchy distribution of stream macroinvertebrates at the riffle-pool scale using a similar procedure and number of replicates (Boyero 2003a, 2003b). The pooled sampled areas per habitat unit (i.e. riffle) was $0.1875 \mathrm{~m}^{2}$ against $0.0675 \mathrm{~m}^{2}$ in Boyero (2003a, 2003b). Consequently, the number of replicates and the area sampled in our study appeared to be representative for comparing the characteristics of caddisfly assemblages.

To dislodge caddisflies from the substrate and allow the streamflow to force them into the Surber net, the substrate within the Surber sampler's quadrat frame was agitated by hand to a depth of about $5 \mathrm{~cm}$, followed by careful wiping by hand of all cobble and gravel pieces. Each sample was placed in a container with 5\% formalin and identified based on Waringer \& Graf (1997). The list of species, and the corresponding functional groups are given in Appendix 1. Unfortunately, two samples were lost, thus they should be omitted from the analyses.

\section{Data processing and statistical analysis}

Six properties were used to characterise caddisfly assemblages. Species richness and density reflect assemblage structure, while the per cent ratio of shredders, collectors, scrapers and predators reflect functio- nal attributes of the caddisfly assemblage (Cummins 1973). The first two properties were standardised to square meter. Functional properties were determined following Moog (1995) and Cummins (1973). The effect of stream order, riverbed morphology and season on caddisflies were evaluated using Multivariate Analysis of Variance (MANOVA, Zar 1999). Stream order, riverbed morphology and season were regarded as factors (i.e. independent variables), while species richness, density, percent ratio of shredders, collectors, scrapers and predators were dependent variables. To elucidate the effects of factors on each dependent variable individually, three-way Analyses of Variance (ANOVA, Zar 1999) were performed separately. Nonmetric Multidimensional scaling (NMDS, Podani 1997) using percentage difference coefficient (Podani 1997) was run to show similarity pattern of caddisfly assemblages of pool and riffle habitats in the second and third order reaches of the Kemence stream system. Multi-Response Permutation Procedure (MRPP, McCune \& Grace, 2002) was used to test, whether species composition of caddisflies in second and third order reaches of pools and riffles was different. Indicator species analysis (Dufrene \& Legendre 1997) was applied to find indicator species for the different states of stream order and riverbed morphology. The significance level of the indicator value was defined by Monte Carlo randomisation with 1000 runs. NMDS, MRPP and Indicator species analysis were performed using the pooled samples over the whole season. MANOVA and ANOVA were performed using STATISTICA computer program (Statsoft, Inc 2000); NMDS by SYN-TAX (Podani 1993); MRPP and Indicator species analysis by PC-ORD (McCune \& Mefford 1997). The result of NMDS was visualised by STATISTICA program.

Table 2. Result of MANOVA assessing the effect of (1) season, (2) stream order and

(3) riverbed morphology on the assemblage structure and function of caddisflies.

\begin{tabular}{cccccc}
\hline Source & $\begin{array}{c}\text { Wilks' } \\
\text { Lambda }\end{array}$ & F & Effect df & Error df & p-level \\
\hline 1 & 0.3100 & 2.8657 & 10 & 36 & 0.0099 \\
2 & 0.4566 & 4.2842 & 5 & 18 & 0.0096 \\
3 & 0.3802 & 5.8689 & 5 & 18 & 0.0022 \\
12 & 0.2659 & 3.3813 & 10 & 36 & 0.0034 \\
13 & 0.4305 & 1.8870 & 10 & 36 & 0.0799 \\
23 & 0.3714 & 6.0936 & 5 & 18 & 0.0018 \\
123 & 0.2921 & 3.0608 & 10 & 36 & 0.0065 \\
\hline
\end{tabular}


Table 3. Summary of ANOVA assessing the effect of (1) season, (2) stream order and (3) riverbed morphology on the richness, density, per cent ration of shredders, collectors, scrapers and predators of caddisfly assemblages.

\begin{tabular}{|c|c|c|c|c|c|c|}
\hline Dependent & Source & $\mathrm{SS}$ & df & MS & $\mathrm{F}$ & p-level \\
\hline \multirow{8}{*}{ Richness } & 1 & 0.2348 & 2 & 0.1174 & $0.11 \overline{48}$ & 0.8921 \\
\hline & 2 & 1.4423 & 1 & 1.4423 & 1.4103 & 0.2477 \\
\hline & 3 & 1.8526 & 1 & 1.8526 & 1.8114 & 0.1920 \\
\hline & 12 & 7.5000 & 2 & 3.7500 & 3.6667 & 0.0422 \\
\hline & 13 & 0.0926 & 2 & 0.0463 & 0.0453 & 0.9558 \\
\hline & 23 & 2.8269 & 1 & 2.8269 & 2.7641 & 0.1106 \\
\hline & 123 & 0.3533 & 2 & 0.1767 & 0.1727 & 0.8425 \\
\hline & Error & 22.5000 & 22 & 1.0227 & & \\
\hline \multirow{8}{*}{ Density } & 1 & 1383.3726 & 2 & 691.6863 & 3.3265 & 0.0547 \\
\hline & 2 & 290.8269 & 1 & 290.8269 & 1.3987 & 0.2496 \\
\hline & 3 & 416.8269 & 1 & 416.8269 & 2.0046 & 0.1708 \\
\hline & 12 & 252.1904 & 2 & 126.0952 & 0.6064 & 0.5542 \\
\hline & 13 & 61.0200 & 2 & 30.5100 & 0.1467 & 0.8644 \\
\hline & 23 & 1495.4423 & 1 & 1495.4423 & 7.1920 & 0.0136 \\
\hline & 123 & 1575.4793 & 2 & 787.7396 & 3.7885 & 0.0386 \\
\hline & Error & 4574.5000 & 22 & 207.9320 & & \\
\hline \multirow{8}{*}{ Shredders } & 1 & 1792.4558 & 2 & 896.2279 & 9.4653 & 0.0011 \\
\hline & 2 & 1753.5037 & 1 & 1753.5037 & 18.5193 & 0.0003 \\
\hline & 3 & 1208.2988 & 1 & 1208.2988 & 12.7612 & 0.0017 \\
\hline & 12 & 828.4894 & 2 & 414.2447 & 4.3750 & 0.0251 \\
\hline & 13 & 873.1335 & 2 & 436.5667 & 4.6107 & 0.0213 \\
\hline & 23 & 2098.5044 & 1 & 2098.5044 & 22.1630 & 0.0001 \\
\hline & 123 & 1934.5197 & 2 & 967.2598 & 10.2155 & 0.0007 \\
\hline & Error & 2083.0743 & 22 & 94.6852 & & \\
\hline \multirow{8}{*}{ Collectors } & 1 & 439.1046 & 2 & 219.5523 & 1.1959 & 0.3213 \\
\hline & 2 & 2022.9249 & 1 & 2022.9249 & 11.0190 & 0.0031 \\
\hline & 3 & 684.0567 & 1 & 684.0567 & 3.7261 & 0.0666 \\
\hline & 12 & 928.9340 & 2 & 464.4670 & 2.5300 & 0.1026 \\
\hline & 13 & 2153.1168 & 2 & 1076.5584 & 5.8641 & 0.0091 \\
\hline & 23 & 1780.9567 & 1 & 1780.9567 & 9.7010 & 0.0050 \\
\hline & 123 & 118.6606 & 2 & 59.3303 & 0.3232 & 0.7272 \\
\hline & Error & 4038.8560 & 22 & 183.5840 & & \\
\hline \multirow{8}{*}{ Scrapers } & 1 & 48.8420 & 2 & 24.4210 & 0.4644 & 0.6345 \\
\hline & 2 & 27.9423 & $\overline{1}$ & 27.9423 & 0.5314 & 0.4737 \\
\hline & 3 & 607.1969 & 1 & 607.1969 & 11.5471 & 0.0026 \\
\hline & 12 & 469.8671 & 2 & 234.9335 & 4.4678 & 0.0235 \\
\hline & 13 & 96.2169 & 2 & 48.1085 & 0.9149 & 0.4153 \\
\hline & 23 & 5.1024 & 1 & 5.1024 & 0.0970 & 0.7584 \\
\hline & 123 & 181.4641 & 2 & 90.7320 & 1.7255 & 0.2013 \\
\hline & Error & 1156.8511 & 22 & 52.5841 & & \\
\hline \multirow{8}{*}{ Predators } & 1 & 1083.1969 & 2 & 541.5984 & 1.8579 & 0.1797 \\
\hline & 2 & 70.3606 & 1 & 70.3606 & 0.2414 & 0.6281 \\
\hline & 3 & 7319.9038 & 1 & 7319.9038 & 25.1098 & 0.0001 \\
\hline & 12 & 6453.2621 & 2 & 3226.6310 & 11.0685 & 0.0005 \\
\hline & 13 & 2366.9561 & 2 & 1183.4781 & 4.0597 & 0.0316 \\
\hline & 23 & 1.8203 & 1 & 1.8203 & 0.0062 & 0.9377 \\
\hline & 123 & 1978.7222 & 2 & 989.3611 & 3.3939 & 0.0519 \\
\hline & Error & 6413.3370 & 22 & 291.5150 & & \\
\hline
\end{tabular}

\section{Results}

When the effects of stream order, riverbed morpho- logy or season were studied separately, MANOVA showed that they had a significant effect on caddisfly assemblages (Table 2). When the interactions of two of 

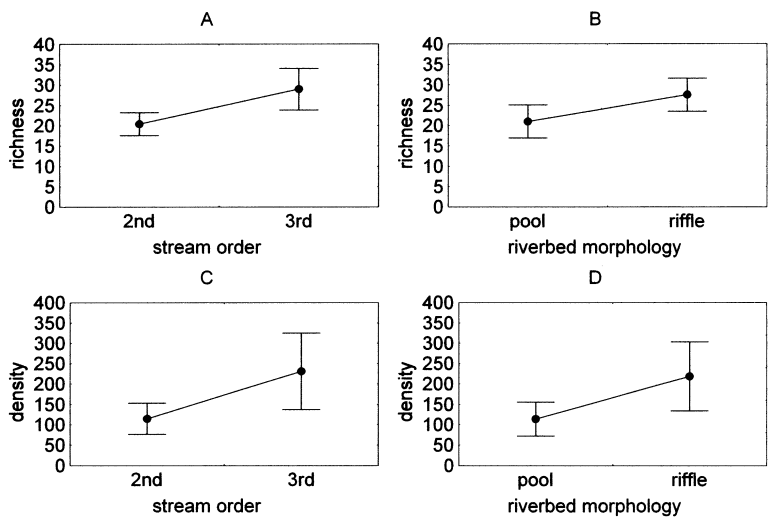

Fig. 1. Response of richness (A and B) and density (C and D) of caddisflies to stream order (A and $\mathrm{C}$ ) and riverbed morphology (B and D). (Dots show mean values, vertical bars show standard errors).

these factors were studied, then two out of three cases showed significant results: the joint effect of season and stream order, and that of stream order and riverbed morphology. In contrast, the combined effect of season and riverbed morphology was not significant. Finally, the combined effect of season, stream order and riverbed morphology showed a significant influence on caddisfly assemblages, too (Table 2). Species richness showed dependence only on the joint effect of season and stream order; whereas density was influenced by the joint effect of stream order and riverbed morphology, and by the joint effect of season, stream order and riverbed morphology (Table 3). Neither species richness nor density of caddisflies was influenced by the

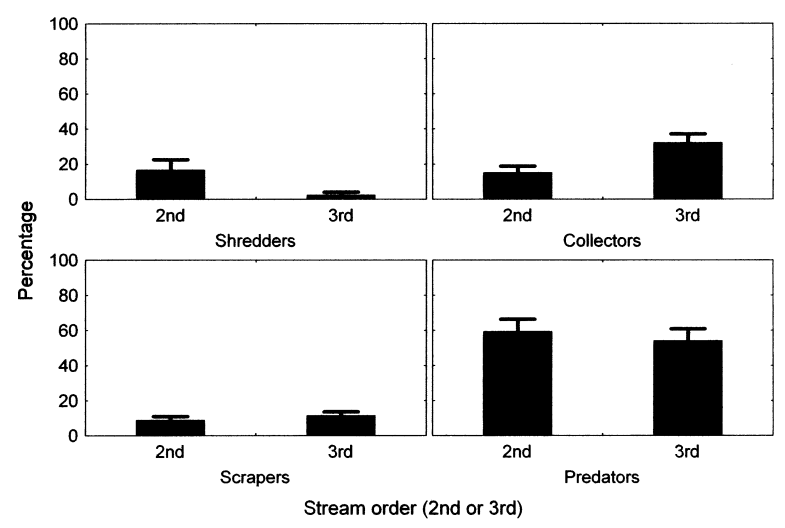

Fig. 3. Response of functional attributes of caddisflies (shredders, collectors, scrapers and predators) to stream order.

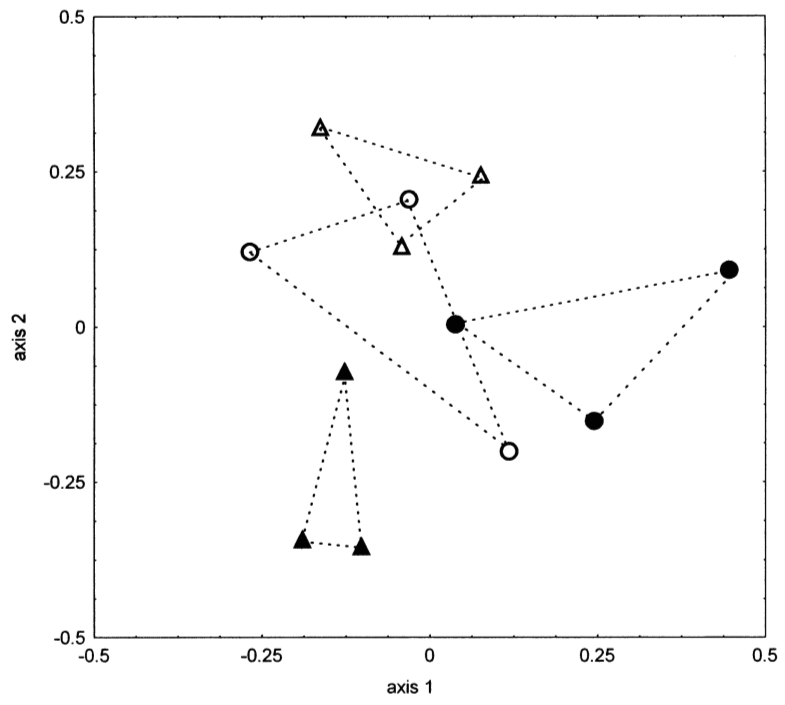

Fig. 2. Result of Non-metric Multidimensional Scaling showing the similarity patterns of caddisfly assemblages collected from pool (circle) and riffle (triangle) habitats in second (open circle or triangle) and third (filled circle or triangle) order reaches of the Kemence stream system.

individual effect of riverbed morphology or stream order (Fig 1).

NMDS could clearly distinguish the four groups of assemblages, although a limited overlap appeared in the ordination space for riffle and pool assemblages collected in the second order reaches (Fig. 2). MRPP showed that caddisfly assemblages collected at $2^{\text {nd }}$ and $3^{\text {rd }}$ order streams were different $(\mathrm{T}=-2.0729$,

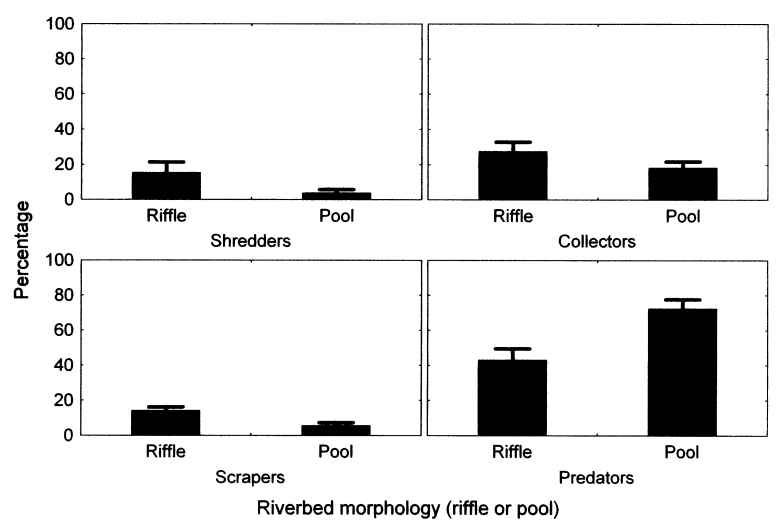

Fig. 4. Response of functional attributes of caddisflies (shredders, collectors, scrapers and predators) to riverbed morphology. 
$\Delta_{\text {observed }}=0.8051, \quad \Delta_{\text {expected }}=0.8519, \quad \mathrm{R}=0.0549$, $\mathrm{p}=0.0287$ ), while assemblages collected from pools and riffles were not $(\mathrm{T}=-0.6976$, ?observed $=0.8361$, ?expected $=0.8519, \mathrm{R}=0.0184, \mathrm{p}=0.2310$ ). In addition, MRPP showed that the joint effects of riverbed morphology and stream order had a significant effect on the species composition of caddisflies assemblages $\left(\mathrm{T}=-1.9651, \Delta_{\text {observed }}=0.7660, \Delta_{\text {expected }}=0.8519\right.$, $\mathrm{R}=0.1008, \mathrm{p}=0.0427)$. Of the 12 caddisfly species identified (Appendix 1), only Hydropsyche instabilis Curtis 1834 proved to be a significant indicator species of the third order stream reach (Indicator value: 83, $\mathrm{p}=0.015$ ). No species appeared as a significant indicator of pool or riffle habitats.

Functional properties of caddisfly assemblages were sensitive to the effects of season, stream order and riverbed morphology (Table 3). The percent ratio of shredders showed significant dependence upon season, stream order (Fig. 3) and riverbed morphology (Fig. 4, Table 3). In addition, the joint effects of the examined factors showed significant effect on caddisfly assemblages (Table 3 ). The percent ratio of shredders was significantly higher in the second order reach than in the third order one (Fig. 3). Furthermore, shredders were represented by a significantly higher ratio in riffles than in pools (Fig. 4). Percent ratio of collectors was effected by the individual effect of stream order (Table 3, Fig. 3), by the combined effect of season and riverbed morphology; and by the joint effect of stream order and riverbed morphology (Table 3). The percent ratio of collectors was significantly higher in the third order reach than in the second one (Fig. 3). Percent ratio of scrapers was significantly higher in riffles (Table 3, Fig. 4). Neither the individual effect of stream order nor the season affected the ratio of scrapers, whereas their combined effect influenced their ratio (Table 3 ). Percent ratio of predators was significantly higher in pools (Table 3, Fig. 4) and showed significant dependence on the interaction of season and stream order; and upon the season and riverbed morphology (Table 3).

\section{Discussion}

Our results show that season, stream order, riverbed morphology (i.e. pool-riffle geomorphology) and the interaction of these factors had a significant effect on the assemblage organisation of caddisflies in the $\mathrm{Ke}$ mence stream system. Among the studied structural and functional properties, the percent ratio of shredders was influenced the most by the examined factors. The reach scale investigations did not show differences between the second and third order reaches ba- sed on the structural properties (richness and density) of caddisfly assemblages. Nevertheless, NMDS and MRPP showed differences between the species composition of caddisfly assemblages. Hydropsyche instabilis, a stream-dwelling caddisfly usually inhabiting low-ordered streams (Higler \& Tolkamp 1983, Schmera 2003), proved to be a significant indicator of the third-order site.

Literature data (Brown \& Brussock 1991, Carter \& Fend 2001, Rabeni et al. 2002, Townsend et al. 2004) stating that richness and density of macroinvertebrates were higher in riffles than in pools were not statistically supported for Trichoptera, although field data suggested that species richness and density of caddisflies were higher in riffles than in pools. Even if MRPP and NMDS did not distinguish contrasting riffle and pool caddisfly assemblages at a site, riverbed morphology had a significant effect on caddisflies when its joint effect with stream order was tested, suggesting that poolriffle level heterogeneity also influenced structural properties of caddisfly assemblages. Although our study did not underpin statistically the differences in richness and density of caddisflies in riffle and pool habitats (in agreement with Scullion et al. 1982), the unique species composition of riffles and pools received support.

In general, scrapers and collectors tend to inhabit riffles, whereas predators occupy pools (Merritt \& Cummins 1996, Weigel et al. 2003). In our study area, ratio of scrapers was significantly higher in riffles whereas ratio of predators in pools. The percent ratio of shredders showed strong dependence on season, stream order and riverbed morphology in the Kemence stream-system. The contrasting ratio of shredders in pool and riffle habitats might be explained by the differences in the accumulation and retention of coarse particulate organic matter in pool and riffle habitats. According to Brussock \& Brown (1991), coarse particulate matter accumulates on riffles due to the rough and uneven bottom profile of these channel units. Consequently, the amount of particulate organic matter in streams is not only affected by the riparian vegetation (Friberg et al. 2002, Graca 2001) but also by instream habitat features, which may shape the assemblage structure and function of organisms living there (Arscott et al. 2003, González et al. 2003, Jonsson et al. 2001).

In conclusion, this study demonstrated that season, stream order and riverbed morphology both individually and in interaction influenced the structural and functional attributes of caddisfly assemblages in the Kemence stream system. Our results support the view 
on the complex nature of fauna organisation in streams and pay attention to the examination of multifactor effects in our understanding the spatial and temporal patterns of caddisfly assemblages.

\section{Acknowledgements}

We thank Árpád Szentesi, Régis Céréghino, Luz Boyero and two anonymous reviewers for their comments on the manuscript.

\section{References}

Allan J.D. 1995. - Stream ecology. Chapman \& Hall

Arscott D.B., Keller B., Tockner K. \& Ward J.V. 2003. - Habitat structure and Trichoptera diversity in two headwater flood plains, N.E. Italy. Internat. Rev. Hydrobiol., 88, 255-273.

Bacher I. \& Waringer J.A. 1996. - Hydraulic microdistribution of cased caddis larvae in an Austrian mountain brook. Int. Revue ges. Hydrobiol., 81, 541-554.

Beisel J.N., Usseglio-Polatera P. \& Moreteau J.C. 2000. - The spatial heterogeneity of a river bottom: a key factor determining macroinvertebrate communities. Hydrobiologia, 422/423, 163-171.

Beisel J.N., Usseglio-Polatera P., Thomas S. \& Moreteau J.C. 1998. - Stream community structure in relation to spatial variation: the influence of mesohabitat cahracteristics. Hydrobiologia, 389, $73-$ 88.

Bournaud M., Tachet H., Berly A. \& Cellot B. 1998. - Importance of microhabitat characteristics in the macrobenthos microdistribution of a large river reach. Ann. Limnol. - Int. J. Lim., 34, 83-98.

Boyero L. 2003a. - Multiscale patterns of spatial variation in stream macroinvertebrate communities. Ecol. Res., 18, 365-379.

Boyero L. 2003b. - The qualification of local substrate heterogeneity in streams and its significance for macroinvertebrate assemblages. Hydrobiologia, 499, 161-168.

Boyero L. 2003c. - The effect of substrate texture on colonization by stream macroinvertebrates. Ann. Limnol. - Int. J. Lim., 39, 211218.

Brown A.V. \& Brussock P.P. 1991. - Comparison of benthic invertebrates between riffles and pools. Hydrobiologia, 220, 99-108.

Brussock P.P. \& Brown A.V. 1991. - Riffle-pool geomorphology disrupts longitudinal patterns of stream benthos. Hydrobiologia, 220, 99-108.

Carter J.L. \& Fend S.V. 2001. - Inter-annual changes in the benthic community structure of riffles and pool reaches of contrasting gradient. Hydrobiologia 459, 187-200.

Céréghino R., Park Y.-S., Compin A. \& Lek S. 2003. - Predicting the species richness of aquatic insects in streams using a limited number of environmental variables. J. N. Am. Benthol. Soc., 22, 442-456.

Cummins K.W. 1973. - Trophic relations of aquatic insects. Annu. Rev. Entomol., 18, 183-206.

Dufrene M. \& Legendre P. 1997. - Species assemblages and indicator species: the need for a flexible asymmetrical approach. Ecol. Monog., 67, 345-366.

Erôs T., Botta-Dukát Z. \& Grossman G.D. 2003. - Assemblage structure and habitat use of fishes in a Central European submontain stream: a patch-based approach. Ecol. Freshwat. Fish, 12, 141-150.

Friberg N., Larsen A.D., Rodkjaer A. \& Thomsen A.G. 2002. Shredder guilds in tree Danish forest streams contrasting in forest type. Arch. Hydrobiol., 153, 197-215.

Giller P.S. \& Malmqvist B. 1998. - The biology of streams and rivers. Oxford University press, Oxford, pp. 296.

González J.M., Basaguren A. \& Pozo J. 2003. - Macroinvertebrate communities along a third-order Iberian stream. Ann. Limnol. Int. J. Lim., 39, 287-296.

Gordon N.D., McMahon T.A. \& Finlayson, B. L. 1992. - Stream hydrology: an introduction for ecologists. John Wiley \& Sons Ltd., Chicester, England 526 pp.

Graca M.A.S. 2001. - The role of invertebrates on leaf litter decomposition in streams - a review. Internat. Rev. Hydrobiol., 86, 383393.

Habdija I., Radanovic I., Primc-Habdija B. \& Spoliar M. 2002. - Vegetation cover and substrate type as factors influencing the spatial distribution of Trichopterans along a Karstic River. Int. Rev. Hydrobiol., 87, 423-437.

Higler L.W.G. 1975. - Reactions of some caddis larvae (Trichoptera) to different types of substrate in an experimantal stream. Freshwat. Biol., 5, 151-158.

Higler L.W.G. \& Tolkamp H.H. 1983. - Hydropsychidae as bio-indicators. Environ. Monit. Ass., 3, 331-341.

Hynes H.B.N. 1970. - The ecology of running waters. University of Toronto Press, Toronto, Ontario, Canada.

Jonsson M., Malmqvist B. \& Hoffsten P.-O. 2001. - Leaf litter breakdown rates in boreal stream: does shredder species richness matter? Freshwat. Biol., 46, 161-171.

Kerans B.L., Karr J.R. \& Ahlstedt S.A. 1992. - Aquatic invertebrate assemblages: spatial and temporal differences among sampling protocols. J. N. Am. Benthol. Soc., 11, 377-390.

McCune B. \& Grace J.B 2002. - 'Analysis of ecological communities’ MjM Software Design, Glenden Beach, Oregon, USA.

McCune B. \& Mefford MJ. 1997. - Multivariate analysis of ecological data. MjM Software, Gleneden Beach, Oregon, USA.

Merritt R.W. \& Cummins K.W. (eds.) 1996. - An introduction to the aquatic insects of North America, $3^{\text {rd }}$ Edition, Kendall/Hunt $\mathrm{Pu}-$ blishing Co., Dubuque, IA, USA

Moog O. 1995 - Fauna Aquatica Austriaca, Lieferung Mai/95. Wasserwirtschaftkataster, Bundesministerium für Land- und Forstwirtschaft, Wien.

Park Y.-S., Céréghino R., Compin A. \& Lek S. 2003. - Application of artificial networks for patterning and predicting aquatic insect species richness in running waters. Ecol. Model., 160, 265-280.

Podani J. 1993. - SYN-TAX. Computer program for multivariate data analysis in ecology and systematics. Abstracta Botanica, 17, 289-302.

Podani J. 1997. - Introduction into the exploration of multivariate biological data. Scientia Kiadó, Budapest, pp. 412.

Rabeni C.F., Doisy K.E. \& Galat D.L. 2002. - Testing the biological basis of stream habitat classification using benthic invertebrates. Ecol. Appl., 12, 782-796.

Schmera D. 2003. - Assessing stream dwelling caddisfly assemblages (Insecta: Trichoptera) collected by light traps in Hungary. Biodiv. Conserv., 12, 1175-1191.

Scullion J., Parish C.A., Morgan N., Edwars R.W. 1982. - Composition of benthic invertebrate fauna and substratum composition in riffles and pools in the impounded River Eland and the unregulated River Wye, mid-Wales. Freshwat. Biol., 12, 579-595.

StatSoft, Inc. 2000. - STATISTICA for Windows [Computer program manual]. Tulsa, OK.

Strahler A.N. 1952. - Dynamic basis of geomorphology. Geological Society of America Bulletin, 63, 1117-1142.

Townsend C.R. 1989. - The patch dynamics concept of stream community ecology. J. N. Am. Benthol. Soc., 8, 36-50.

Townsend C.R., Dolédec S \& Scarsbrook M.R. 1997. - Species traits in relation to temporal and spatial heterogeneity in streams: a test of habitat templet theory. Freshwat. Biol., 37, 367-387.

Townsend C.R., Downec B.J., Peacock K., Arbuckle C.J. 2004. Scale and the detection of land-use effects on morphology, vege- 
tation and macroinvertebrate communities of grassland streams. Freshwat. Biol. 49, 448-462.

Usseglio-Polatera P., Thomas S., Beisel J.N., Moreteau J.C. 1999. Biological traits structure of macroinvertebrate benthic communities. Ann. Limnol. - Int. J. Lim., 35, 71-80 (In French).

Vinson M.R. \& Hawkins C.P. 1998. - Biodiversity of stream insects: variation at local, basin and regional scales. Annu. Rev. Entomol. 43, 271-293.

Ward J.V. 1998. - The four-dimensional nature of lotic ecosystems. J. N. Am. Benthol. Soc. 8, 2-8.

Waringer J. \& Graf W. 1997. - Atlas der Österreichischen Köcherfliegenlarven. Fakultas Universitatverlag, Wien, pp. 286

Weigel N.M., Wang L., Rasmussen P.W., Butcher J.T., Stewart P.M., Simon T.P. \& Wiley M.J. 2003. - Relative influence of variables at multiple spatial scales on stream macroinvertebrates in the Northern Lakes and Forest ecoregion, U.S.A. Freshwat. Biol., 48, 1440-1461.

Wiberg-Larsen P., Brodersen K.P., Birkholm S., Gron P.N. \& Skriver J. 2000. - Species richness and assemblage structure of Trichoptera in Danish streams. Freshwat. Biol., 43, 633-647.

Zar J.H. 1999. - Biostatistical analysis. Fourth edition. Prentice Hall, New Jersey, pp. 663.
Appendix 1:

List of collected caddisfly species and their partition into the main functional groups (Cummins 1973)

\begin{tabular}{lc}
\hline SPECIES & FUNCTIONAL GROUP \\
\hline Rhyacophilidae & predator \\
Rhyacophila fasciata Hagen, 1859 & \\
Hydropsychidae & collector \\
Hydropsyche contubernalis McLachlan, 1865 & collector \\
Hydropsyche instabilis Curtis, 1834 & collector \\
Hydropsyche saxonica McLachlan, 1884 & \\
Limnephilidae & shredder \\
Anabolia furcata Brauer, 1857 & shredder \\
Potamophylax rotundipennis (Brauer, 1857) & \\
Philopotamidae & collector \\
Philopotamus montamus (Donovan, 1813) & \\
Polycentropodidae & predator \\
Cyrnus trimaculatus (Curtis, 1834) & predator \\
Plectrocnemia conspersa (Curtis, 1834) & predator \\
Polycentropus flavomaculatus (Pictet, 1834) & \\
Beraeidae & scarper \\
Beraeodes minuta (Linnaeus, 1761) & \\
Leptoceridae & shredder \\
Athripsodes bilineatus (Linnaeus, 1758) &
\end{tabular}

